\title{
O fogo e as chamas dos mitos
}

\author{
BETTY MINDLIN
}

\section{A selva dos mitos}

Q

UASE TODOS os povos indígenas brasileiros contam preciosas histórias so-

bre a origem do fogo. Muitos relatam incêndios que teriam destruído a

terra, assim como há histórias de inundações e dilúvios que exterminaram a humanidade.

Haverá algum sentido em buscar nos mitos uma correspondência com fenômenos climáticos arcaicos, com a destruição das florestas pelo fogo, ou com a criação de desertos, já que os mitos vêm de épocas antigas?

Saber o que os mitos são é um desafio. Eles continuam a esconder um significado misterioso através das análises, as mais variadas, e uma infinidade de definições e explicações têm sido propostas. A palavra mito, como se sabe, vem do grego e significa, narrativa contada. Há uma definição sucinta e muito útil, bastante apoiada em Mircea Eliade, que vale a pena transcrever:

"MITO: NARRATIVA tradicional sobre o passado que freqüentemente inclui elementos religiosos e fantásticos. Alguns tipos de mitos são encontrados em todas as sociedades, embora funcionem de diferentes maneiras em cada uma delas. Os mitos podem tentar explicar a origem do universo, e da humanidade, o desenvolvimento de instituições políticas ou as razões das práticas rituais. Os mitos muitas vezes descrevem as façanhas de deuses, de seres sobrenaturais, ou de heróis que têm poderes suficientes para se transfigurar em animais e para executar outra proezas extraordinárias. Antropólogos passaram muito tempo tentando diferenciar mito de história, mas a história pode exercer as mesmas funções do mito, e os dois tipos de narrativas sobre o passado algumas vezes se confundem. Teóricos como Frazer interpretavam os mitos como formas de antigos pensamentos científicos ou religiosos. Esta abordagem foi posteriormente criticada por Malinowski, que via o mito como explicação para a ordem social. O historiador romeno norte-americano Mircea Eliade (1907-86) via o mito como um fenômeno religioso, isto é como a tentativa de o homem retornar ao ato original da criação. Lévi-Strauss afirmou que a importância do mito não está em seu conteúdo, mas em sua estrutura, uma vez que ela revela processos mentais universais. Em psicologia os mitos são vistos como uma importante base para o comportamento humano Tanto Freud quanto Jung utilizaram largamente os mitos em seus trabalhos. Quaisquer que sejam as teorias a respeito das origens e funções dos mitos, esses permanecem fundamentais para a consciência humana" (1). 
Para os índios, a mitologia é a verdadeira história do mundo - não é fantástica nem mito como nós o vemos. Mircea Eliade (2) insiste em que se deveria pensar em mitos vivos para apreender o seu significado, e uma das nossas dificuldades é que foi na cultura grega que os mitos gregos foram estudados conceitualmente em maior profundidade e, justamente na Grécia, foram reduzidos, ao longo do tempo, ao caráter de ficção, em contraste com as nascentes filosofia e ciência no século de Péricles.

Na maior parte dos 200 povos indígenas brasileiros, a mitologia é ainda viva, transmitida oralmente de uma geração a outra. Nos Suruí de Rondônia, autodenominados Paiter (plural Paiterei), Gente Verdadeira, Nós Mesmos, com os quais convivi, ao todo, cerca de um ano e meio, o caráter histórico que conferiam à mitologia saltava aos olhos. Quando conversávamos sobre a teoria da evolução, de Darwin, por exemplo, afirmavam que sua teoria era semelhante, mas exatamente contrária: na sua história, diziam, os bichos, antigamente, no início do mundo, eram gente, e foram se transformando em animais segundo narrativas que contam.

Interessante seria conseguirmos compreender os mitos na perspectiva dos valores da sociedade em que surgem, com conhecimento do contexto - como o faz, por exemplo, Vernant (1973, 1992, 1994; Vernant \& Vidal-Naquet, 1998) para a Grécia: uma tarefa nada fácil.

Uma coisa é a idéia de mito como a história do povo que o conta; outra a do mito como correspondente à nossa história, por exemplo, para pensarmos na ligação entre mito e fenômenos naturais arqueológicos.

Há muitos problemas, porém, em tomar os mitos ao pé da letra, como registros da história natural. A que períodos poderiam se referir? Os mitos são seguramente muito antigos, arcaicos, mas é difícil datá-los. Seria desejável que pudéssemos ter um método semelhante ao teste do carbono $14 \mathrm{em}$ cima de narrativas transmitidas oralmente, por exemplo, um método lingüístico... mas a idade de um mito fica para o domínio da especulação.

A explicação dos mitos como lembranças ou registros modificados de fenômenos naturais é apenas uma das numerosíssimas perspectivas possíveis - todas elas, cada uma a seu modo, bastante convincentes ou atraentes.

Talvez a teoria dos mitos indígenas mais divulgada hoje seja a de Claude Lévi-Strauss, que equiparou a dignidade do pensamento indígena à da cultura clássica greco-romana e ao pensamento científico. Para Lévi-Strauss, não há um significado unívoco num mito, embora sua substância também tenha importância e possa ser melhor compreendida à luz da sociedade específica que o produziu. O que importa é a linguagem estabelecida pelos mitos entre si, a estrutura dos mitos, que corresponderia a estruturas mentais. Os mitos poderiam ser entendidos como os componentes de um imenso cristal geométrico - devendo-se de- 
cifrar as relações que estabelecem entre si, as facetas lapidadas da pedra, ligações que surgem de oposições duais, aspectos a perceber na sociedade e na natureza.

O mito do roubo do fogo nos Kaiapó, que será resumido a seguir, por exemplo, contém partes que se referem ao ciúme, ao predador do ninho de passarinhos, e que se ligam ao incesto entre mãe e filho de outro mito Bororo, motivos que aparecem transformados em outras culturas e em outros mitos. Compreender o porquê, ou melhor, a forma ampla dessas semelhanças e diferenças, dessas relações, é o verdadeiro enigma. A análise que Lévi-Strauss (1967:237-265) faz do mito de Édipo é paradigmática.

Quanto ao mito do fogo, tão relevante no nosso caso, adquire uma importância fundamental na obra de Lévi-Strauss (1991) - O cru e o cozido, por exemplo - por ser o marco da distinção entre natureza e cultura, coleta e cozinha, alimentação animal ou cultural, esta ligada aos símbolos e à sociedade. Lévi-Strauss afirma que usa categorias empíricas como cru e cozido, fresco e podre, molhado e queimado, dentro do ponto de vista de uma cultura particular, para isolar noções abstratas, compreender a linguagem dos mitos entre si, as transformações de uns nos outros.

Ao mesmo tempo, isolar mitos do fogo ou do incêndio fica mais complicado, já que pertencem a uma totalidade - o que se pode é seguir suas pistas em partes da estrutura do cristal da mente humana e da mitologia. Idéias complexas, que são desenvolvidas, por exemplo, na obra interessante e de leitura fluente sobre a teoria de Lévi-Strauss: o livro de Octavio Paz (1967), um ensaio poético e profundo sobre o grande antropólogo.

Lévi-Strauss permite uma visão ampla da mitologia e estimula a mergulhar no significado profundo de cada mito, para quem não se deixar emaranhar por sua preocupação com o conjunto e com a complexidade da análise, o mito sobre os mitos, o metamito que constrói.

Muitos outros autores nos levam por trilhas bem diferentes pela selva dos mitos. Não é possível, num curto ensaio, sequer tentar resumir ou enumerar essas grandes especulações. Vale a pena lembrar, porém, que hoje não se fala em mito sem pensar em Freud e em Jung, e em suas explorações da mente humana, do inconsciente, dos arquétipos, do incesto, da sexualidade, do imaginário, dos sonhos, da criação artística, que buscam correspondências no sentido luminoso e na substância de cada relato mítico. Ou que Propp $(1970,1983)$ abriu vastos caminhos para a análise dos contos fantásticos, mostrando a regularidade de funções nos enredos, como as ações (matar, salvar, trair, casar etc). Os assuntos e temas seriam intercambiáveis, trocando entre si, não explicando a regularidade existente no conto maravilhoso - as funções é que seguiriam um padrão regular.

Campbell (1990), um grande estudioso de mitologia, muito apoiado em Jung, vê a mitologia como uma metáfora ou expressão da relação do homem 
com a natureza. Um dos núcleos mais imediatos seria então o nascimento: o lugar escuro de onde surgimos, a passagem estreita, a relação com a luz. A primeira experiência de qualquer ser é o corpo da mãe, e haveria na mitologia uma relação de busca de harmonia com o universo, com a sociedade, com a natureza e com o ambiente. Quando a sociedade vai mudando, os mitos teriam de ser outros...

A mitologia como forma de compreender a psicologia é um assunto inesgotável. Marie-Louise von Franz (1972), uma analista junguiana, incorpora bastante os mitos indígenas ás suas análises, principalmente os norte-americanos, em especial os mitos de criação.

Estas observações resumidas tiveram o intuito de apontar que a simplicidade de tomar temas como fogo, ou dilúvio, ou cataclismas ou apocalipses é apenas aparente, poderia mesmo ser contestada. Por outro lado, se teorizar não tem fim, pode-se pelo menos tentar trazer à tona o manancial do imaginário indígena, submerso na cultura brasileira, tão diverso e gigantesco, se seguirmos um fio temático.

No pouco espaço deste artigo, com uma mistura de métodos, nenhum em particular, de forma intuitiva, informando mais que analisando, quem sabe se consegue acender o fogo, expondo um fragmento pequeno do tesouro mitológico dos índios brasileiros. Analistas e investigadores qualificados poderão proceder a novas teorizações.

\section{O roubo do fogo}

Um tema freqüente em culturas variadas é o do desafio à ordem divina, a apropriação do fogo pelos mortais. Nos mitos gregos, Prometeu é quem rouba o fogo dos deuses.

Diz Vernant que Prometeu representa no Olimpo uma vozinha de contestação, espécie de movimento estudantil de maio de 1968. Zeus decide esconder dos homens o fogo, antes disponível para todos, mortais e imortais, na copa de certas árvores - os freixos - porque Prometeu tentara tapeá-lo numa repartição da carne de um touro entre deuses e homens. Prometeu envolvera os ossos do animal em sebo, com a aparência de muita carne, e separara a carne num bucho pouco apetitoso. Zeus escolhera o primeiro embrulho para os deuses. Furioso com o logro, esconde o fogo, o que é uma catástrofe para os homens, impedidos de cozinhar. Prometeu sobe ao céu com um galho de uma planta - o funcho -, rouba uma semente do fogo de Zeus e a traz para a terra ardendo no funcho. Prometeu distribui o fogo entre os homens, novamente provocando a ira de Zeus, que também tira dos homens o alimento da vida, os cereais, a própria vida.

Antes, não era preciso trabalhar, fazer esforço para trabalhar. Agora, os mortais terão de esconder as sementes, dissimuladas por Prometeu que as rou- 
ba, no ventre da terra - nasce a agricultura e é preciso guardar a semente de um ano para o outro, não comer todo o cereal. Os homens são obrigados a viver trabalhando.

O fogo que redescobrem não é o mesmo que Zeus escondeu. O de Zeus é o fogo celeste, que nunca enfraquece, um fogo imortal. O fogo roubado por Prometeu, que vem de uma semente de fogo, é um fogo que morre, deve ser vigiado para ser preservado. Tem um apetite semelhante ao dos mortais, faminto (Vernant, 2000: 59-68). Agora o fogo tem que ser alimentado com lenha.

É curioso que, na Bíblia, a origem do fogo isoladamente não apareça: o desafio aos deuses, ou a Deus, se faz com outros núcleos, como a Torre de Babel, a arrogância mortal de alcançar os céus, ou a maçã de Eva, a queda do paraíso. A separação do céu e da terra, o desabamento do céu, a queda do paraíso, são outras formas de ver o distanciamento ou a aproximação proibida, sempre presente na mitologia, entre os deuses e a humanidade.

O mito grego é um eco forte aos mitos indígenas do fogo, sem equivalente tão delineado na tradição judaico-cristã.

\section{Os Jê e o fogo}

Nos índios, são animais variados, com freqüência, os donos originais do fogo. No mito Kaiapó-Gorotire da origem do fogo, um homem é abandonado pelo cunhado no alto de uma rocha porque foram juntos apanhar ninhos de arara, e quando o que subiu atira os ovos ao de baixo, estes se transformam em pedras. O que fica preso passa sede e fome, até ser salvo por uma onça pintada (macho). O onça o leva e lhe serve carne assada, que o homem não conhecia, pois a humanidade não tinha fogo. A mulher do onça, com o tempo, tenta devorar o rapaz, que um dia a mata e foge, levando a carne assada para sua aldeia. Os homens organizam uma expedição à casa das onças para roubar o fogo.

Este mito existe de forma muito semelhante em outros povos Jê, como os Kaiapó, os Timbira orientais, os Xerente, os Apinaié, os Krahô. Entre estes, Lévi-Strauss reconta várias versões. Os Suyá, por exemplo, têm um mito bastante parecido, documentado por Anthony Seeger (Wilbert, 1984: 108-110). Nessa versão, alguns animais ajudam os homens a roubar o fogo do jaguar; o sapo deixa as brasas se extinguirem na água, o tucano e o tapir são bem sucedidos. A onça, depois do roubo do fogo, é condenada a comer carne crua.

Com sua característica mágica de transformação, o mesmo mito do rapaz abandonado no alto da rocha, em versão modificada, passa a centrar-se no apagar do fogo, em vez de seu dom, e tem como núcleo o incesto. É o que ocorre com um mito Bororo (povo, aliás, que não é Jê). $\mathrm{O}$ mito poderia ser assim resumido: Um homem descobre que seu filho está namorando a madrasta, sua segunda mulher, o que é incestuoso neste povo. Tenta matar o filho submeten- 
do-o a provas dificílimas, como caçar animais ferozes, ir ao país dos mortos, roubar frutas guardadas por espíritos. O rapaz, graças aos conselhos da avó, sempre consegue vencer. Numa caçada de aves, o pai abandona o filho no alto de uma rocha, mas o jovem atrai abutres que o levam para o chão, comendo, porém, seu ânus e nádegas. Arrastando-se, o jovem refaz a parte do corpo que perdeu com tubérculos. Vai à procura de seu povo. Avisa a avó que entrará em sua casa como lagartixa. Neste instante, uma tempestade se abate sobre a aldeia, apagando todos os fogos menos o da avó. O herói, secretamente, entra na casa da avó, como lagartixa, escondendo-se do pai. Reaparece em forma humana, sendo reconhecido pelo pai e pela madrasta. Transforma-se num cervo e mata o pai (Albisetti \& Venturelli, 1969: 303-309).

Para quem conhece muitos mitos, essa mistura de motivos é característica. O herói perseguido ou desprezado pelo pai, autor ou não de suposto crime de incesto, que volta incógnito para casa, como um Ulisses depois da guerra de Tróia, e se transforma em lagartixa para não ser identificado, existe em mitos de Rondônia. No entanto, o tema das aves, do incesto e do abandono nas alturas liga esse mito também ao roubo do fogo, que aqui inexiste. Também a oposição entre o pai de família protetor (por vezes o jaguar) e a avó, perseguidora, que está invertido no mito Bororo, com o pai perseguidor e a avó acolhedora, reaparece em muitos mitos do fogo.

\section{A origem do fogo em alguns povos indígenas de Rondônia}

Para os Suruí, Paiterei, também a onça, Mekô, era o dono do fogo. O Criador, Palop, literalmente Nosso Pai, pede ao passarinho Orobab, preto, com cauda comprida, que vá roubar o fogo para a humanidade, que passa frio e não tem como cozinhar. Para que Orobab não seja devorado de imediato, Palop passa uma substância amarga no corpo do pássaro. Orobab vai, conversa com Mekô, distrai a onça, senta-se bem perto do fogo, ignorando os avisos da onça para que não queime o rabo, e chamusca suas penas, voando em fuga. Ao chegar perto dos homens, senta-se na árvore de urucum, em uma outra árvore cujo nome em português não está identificado, e por último no pau-brasil. Os Paiterei costumavam fazer fogo friccionando galhos de quaisquer dessas três árvores. Assim é que os Paiterei conseguiram o fogo, segundo contam na historia do fogo (Mindlin et al., 1996: 90-91).

Nem sempre, porém, o dono original do fogo era a onça. Para os Macurap, um povo de Rondônia, o Veado era o dono do fogo, e não queria dá-lo a ninguém. Um dos dois criadores, Beüd, cujo companheiro tem o nome de Nambu, aproxima-se dele, dorme numa rede ao seu lado, e se transforma em calango. Jogando um tição nas próprias costas, atira-se ao rio. O Veado fez as águas subirem, mas mesmo assim Beüd conseguiu levar o fogo ao companheiro Nambu. 
Este, porém, para amolar o irmão, apaga o fogo. Nambu sabia fazer fogo e não fazia nem ensinava; mas quando Beüd conseguiu virar calango e roubar a brasa, Nambu mostrou que era mais sabido. Pegou dois feixes de pau, esfregou um no outro, e fez fogo, distribuindo a toda gente em capembas de ouricuri (Mindlin, et al., 1999: 39-41).

Para os Aruá, outro povo de Rondônia, próximo aos Macurap, mas falantes de uma língua tupi-mondé e não tupi da família tupari, como os Macurap, são os dois demiurgos, Paricot e Andarob, que roubam o fogo, cujo dono era o Pica-pau. Os dois malandros sopram todos os insetos em cima do Pica-pau; este, aperreado, solta o tição. Depois, vendo que foi logrado, incendeia a terra, queimando os dois criadores. É a irmã de ambos, Antoinká, quem os ressuscita, soprando fumaça de cigarro, feito das cinzas, nos despojos queimados dos dois (Idem: 60) É interessante notar que, embora sendo os deuses criadores, os irmãos ainda não possuíssem ou controlassem o fogo...

Nos Jabuti de Rondônia, os dois demiurgos, Kawewé e Karupshi, queriam derrubar a árvore de pedra, pois se seus frutos de rocha caíssem, poderiam exterminar a humanidade. Sabiam que o Pica-pau tinha um machado potente, capaz de cortar a árvore. Todos os outros pássaros tinham quebrado o bico tentando abatê-la. Ora, o Pica-pau era também o dono do fogo. Os dois foram pedir o fogo e Pica-pau não quis dar. Kawewé virou então uma abelhinha e entrou no olhos de Pica-pau; Karupshi virou uma formiga e mordeu o dono do fogo. Um deles roubou o machado, o outro o fogo. O Pica-pau, furioso, queimou-os, mas Karupshi, escondido no buraco do tatu, escapou ileso, e ressuscitou o irmão. Com o machado, fizeram cair a árvore de pedra e dividiram o fogo entre os seres humanos.

Vê-se que machado e fogo estão associados em muitos mitos - e machado, se formos seguir o tema, está muito associado à emergência da humanidade, que vivia debaixo da terra antes de o mundo ser povoado, ou vivia presa dentro de rochas que devem ser partidas, o que só os pássaros possuidores de um bico muito duro são capazes de fazer, aqueles que têm o machado mais resistente. Do fogo, passaríamos à criação, a uma mulher grávida que ao sair do subterrâneo fica entalada na pedra, e a mil outros núcleos de enredos... A árvore de pedra, que em outras mitologias existe como árvore da vida, ou como a árvore da tentação do paraíso, é outro núcleo central.

Há um povo de Rondônia quase extinto, os Ajuru, contando apenas com um punhado de velhinhos, que não conseguiram ensinar a língua à geração seguinte, que conta ter sido Kupekarantô o Dono do Fogo. Este estava derrubando, com seu machado de pedra, uma árvore que segurava o céu. O céu já caíra três vezes, matando muita gente; este era o quarto céu. Os dois irmãos demiurgos, Xtarontin e Wakowereb, viravam aranhas, cobras, mordiam o Dono do Fogo, mas este nem ligava, continuava com o machado. Finalmente os dois viraram 
mutuca, chupando as costas do Dono do Fogo. Este esmigalhou Wakowereb; mas seus farelinhos caíram no chão, juntaram-se, e ele ressuscitou. $\mathrm{O}$ mais velho continuou chupando o sangue de Kupekarantô, que acabou morrendo, soltando o fogo e o machado. Os dois fugiram com os novos dons, mas um deles recomendou ao outro que não olhasse para trás; o outro desobedeceu, e seu olhar fez reviver o Dono do Fogo, que incendiou a terra. Os dois fugiram para a casa da aranha, um deles queimou, o outro salvou-se. A aranha tentou roubar o machado, mas não conseguiu. Depois do fogo, veio uma enchente que matou muita gente (Mindlin et al., 1999: 91-95).

\section{Poder, o dom e o roubo}

Assim, para alguns povos, são os criadores quem dão o fogo - não são os homens quem roubam, mas os próprios magos. Outras vezes, os criadores estimulam os homens a roubar do dono egoísta e avarento. O fogo significa poder, conquista a ser feita.

Segundo os Kuikuro do Alto Xingu, o dono do fogo originalmente era o urubu-rei. Havia um herói demiurgo, Kanassa, que andava sempre com um vagalume na mão fechada. Essa era a única luz que existia, e como ficava dentro da mão dele, havia muita escuridão. Kanassa desenhou no barro uma arraia, mas com o escuro não viu o que ele próprio tinha criado, e foi ferrado. Pediu, então, o fogo à saracura, para poder enxergar - e esta lhe disse que não havia fogo, só o urubu-rei é que tinha. Kanassa desenhou um veado morto, escondeu-se na unha da carniça, e ficou esperando o urubu se aproximar. Quando este começou a comer a carne podre, agarrou-o pelo pé... e só o soltou quando o urubu-rei lhe trouxe o fogo. O urubu-rei só achou ruim um pouquinho, e ainda ensinou os Kuikuro, a fazerem fogo por fricção, com pedaços de flecha e uma varinha de urucum (Villas Boas \& Villas Boas, 1972: 96-100).

No mito dos Kamaiurá, do Alto Xingu, o fogo não é roubado; o Criador, Mavutsinim, ao ver o povo assando peixe ao sol, comendo comida meio crua, ou que demora demais a ficar pronta, ensina a humanidade a fazer fogo por fricção, com cana de ubá (Agostinho, 1974: 61-62).

Um mito parecidíssimo foi registrado por Nunes Pereira (1967: 561-562) entre os Cauaiua-Parintitim, no Amazonas. Baíra, o demiurgo, se faz de morto para atrair o dono do fogo, o urubu, de quem rouba as brasas para dar ao povo Parintintim. O sapo cururu é que consegue, obedecendo às ordens de Baíra, atravessar o rio e chegar aos índios sem deixar apagar o fogo.

\section{O dom do fogo, segundo os Sateré (Pará/Amazonas)}

“Antigamente não existia fogo. Não havia como fazer uma comida gostosa, uma comida assada. Mas havia um homem que se chamava Homem de Fogo, que era feito de fogo, por dentro. Não podia andar 
descuidado, para não queimar os outros.

Certo dia um homem saiu para caçar camarão nos riachos, nos igapós. O Homem de Fogo estava por perto, percebeu o caçador de camarões, cumprimentou-o (naquela época não se usavam os nomes, um homem dizia 'eu sou ain mempyt', 'sou o filho da minha mãe', tratamento de respeito). Fez de um jeito que se encontrassem de frente. Não podiam encontrar-se de costas, seria fatal, iria queimar o homem. Encontraramse, cumprimentaram-se:

- O que você está fazendo?

Estou caçando camarão! E você?

- Eu também! Para onde você vai? De onde você veio?

- Estou vindo da minha aldeia!

Papo vai, papo vem, um foi perguntando ao outro o que estava caçando. O Homem de Fogo perguntou se o outro já apanhara o camarão. $\mathrm{O}$ outro respondeu que pegara duas poquecas cheias. O Homem de Fogo sugeriu que fizessem um assado, mandou preparar um fogo. $\mathrm{O}$ homem que estava caçando camarão pegou lenha seca. O Homem de Fogo viu, indicou que era preciso pegar pau bem verde, com os outros o fogo acabaria imediatamente. Mandou pegar madeira molhada. O outro fez como foi mandado.

- Está pronto!

O Homem de Fogo não queria mostrar sua arte, como acender o fogo. Pedia para o outro afastar-se, mas este queria saber como se faz fogo, curioso, concentrava-se, saiu com cuidado. O Homem de Fogo só fazia passar por cima, já tocava fogo, mesmo a lenha molhada acendia, só no seu pulo. Apareceram brasas. Os dois assaram camarão, peixe. Comeram, fizeram um jantar. $\mathrm{O}$ homem gostou da comida assada, feita no fogo.

- Assim é que eu gostaria de comer, gostaria de ter um fogo para assar, fazer comida gostosa! Comer comida crua com sangue não é gostoso! Vou levar um tição desses!

- Pode levar!

Foi soprando até a sua casa, então entregou para a irmã.

- Vai soprando até pegar fogo, não podemos perder o fogo!

$\mathrm{A}$ irmã, querendo fazer o fogo, deixou a saliva cair por cima, apagou. $\mathrm{O}$ homem que trouxe o fogo ficou bravo com a irmã, deu um tapa na sua boca; a irmã se transformou num caracol, que tem a boca torta por causa do tapa que levou" (Mindlin \& Ramos, 1996: 15-21).

"O homem, preocupado em readquirir o fogo, foi à casa do Dono do Fogo.

- O fogo que eu levei apagou, minha irmã não sabia fazer, deu um fim antes de acender! 
- Se esse fogo pegasse não ia prestar, ia queimar todo mundo, as casas, as pessoas, todo mundo. Não seria nem bom que pegasse o fogo. Felizes as pessoas porque apagou. Vou te dar de outra forma.

Pegou um pauzinho, limpou o ânus e deu para o homem.

- Está aqui! Este é especial, pode usar, leve para sua casa.

Levou para casa, ele mesmo fez o fogo, e funciona até o dia de hoje. É o resultado do trabalho do homem que saiu, procurou, trouxe o fogo".

Segue-se outra narrativa, dos filhos do Homem de Fogo, cujo brinquedo, feito pelo pai, foi roubado por um desconhecido, que o Homem de Fogo persegue. O ladrão do brinquedo tinha um trato com um amigo: se um morresse, o outro deveria ressuscitá-lo, ninguém sabe de que forma. Eis um trecho central do mito:

"O pai, o Homem de Fogo, tinha ido buscar mandioca com a mãe. Quando ouviu os gritos das crianças, veio correndo do roçado, perguntando o que era. Contaram que o tal homem tinha roubado seu brinquedo, uma espécie de maracá.

- Em que rumo correu?

Mostraram. O pai fez sua arte, abaixou-se e o fogo saiu pelo ânus, foi um fogaréu atrás do homem (o pai é o mesmo Dono do Fogo da outra história). O que fugiu fez uma grande selva atrás de si, mas não adiantava, o fogo devorava com rapidez. Quanto mais cerrado e mata criasse, mais o fogo aumentava, as labaredas o perseguiam. Fez um campestre limpo, mas o fogo conseguiu passar atrás dele. Fez um rio muito grande, o fogo conseguiu atravessar o rio. Entrou num buraco, o fogo entrou no buraco. Entrou num pau, o fogo não desistiu. Gritava desesperado, dizendo que já deixara o brinquedo, mas não havia mais jeito. Até que entrou num pau que não tinha mais saída. $\mathrm{O}$ fogo pegou o homem e devorou, queimou todo. Missão cumprida, entregou o corpo do homem para as borboletas.

- Está aí o corpo queimado para as borboletas, podem sugar.

- Assim o primeiro sonho se realizou. O outro, o amigo, soube o que acontecera.

- Como vou fazer? O jeito é recolher os ossos!

Mandou a lagartixa juntar todos os ossos. A lagartixa ajuntou os ossos, mas ficou com alguns ossos do pé e da mão. Por isso nossos dedos não são certinhos, falta um pedaço, A lagartixa tem mãos mais compridas, sinal de que andou roubando ossos da mão e do pé.

Quando o amigo recebeu os ossos, começou a montar em forma de corpo. Apanhou um monte de folhas, especiais para criar carne, amassou e pôs-se a lavar, a derramar água por cima dos ossos, até criarem 
carne. Pegou um cigarro, assoprou em cima do corpo, o morto viveu, levantou.

- Como dormi, tive um pesadelo!

- Você não teve pesadelo, aconteceu o que você estava sentindo, você foi devorado pelas labaredas de fogo!

Ele merecera o castigo, não tinha como se vingar do Dono do Fogo".

O mito continua com outros desastres para o ladrão e outra ressureição, desta vez do amigo do ladrão, que este obtém através das cinzas do morto. É um mito interessante, inédito (não está na bela coleção registrada por Nunes Pereira (1967) em viagens que começaram em 1918), que ouvi entre os Sateré do pajé Vidal da Silva, aludindo a incêndios na terra e ao papel das cinzas no renascimento - um tema encontrado com freqüência entre os índios, e mesmo noutras culturas.

\section{O fogo segundo os Guarani}

Talvez a tradição indígena brasileira (e paraguaia) mais bem documentada seja a dos Guarani. São narrativas místicas, complexas, de difícil tradução, vivas e conservadas mesmo depois de 500 anos de contato, escritas por muitos pesquisadores (3).

O roubo do fogo, segundo a epopéia Guarani, ocorre na terra nova, quando a antiga foi destruída por um dilúvio, marcando a separação entre os deuses e a humanidade depois de um crime de incesto entre o deus Karaí Jeupié e a irmã de seu pai. Os humanos habitam agora uma terra imperfeita, mas como escolhidos dos deuses. Pierre Clastres resume o mito da origem do fogo e nos dá, entre outras, a versão que reproduzo a seguir, com a intenção de exemplificar o estilo poético tão característico dos Guarani: o mito tem grandes semelhanças com o dos Kuikuro, por exemplo, mas o clima da narrativa é muito diferente.

“Os mestres do fogo são os corvos. É preciso roubá-lo deles, a fim de que os futuros habitantes da nova terra possam dispor dele. Personagens que pertencem ao mundo divino encarregam-se de cometer o roubo: heróis culturais, ou semideuses, ou mesmo Sol. Um deles finge-se de morto; os corvos chegam para cozinhá-lo e comê-lo. O falso morto chacoalha-se e espalha as brasas, e o sapo consegue engolir uma pequena quantidade delas que, uma vez vomitada, é colocada no interior de algumas madeiras determinadas. Bastará aos homens, doravante, produzir fogo pelo método da fricção. Notemos que, para os Guarani, a fricção não produz verdadeiramente o fogo, mas permite simplesmente extraílo da madeira, onde já se encontra enclausurado. Quanto aos corvos, despossuídos para sempre do fogo, transformam-se no que estavam condenados a se tornar: corvos, isto é, os comedores de carniça a quem não molestará o fedor da 'coisa grande', nome religioso do cadáver" (Clastres, 1990: 102-103). 


\section{"A origem do fogo}

A terra de nosso pai, o primeiro, sofreu uma destruição, mas já apareceu a terra nova. Então, nosso pai, o primeiro, fala:

- Bom! Vá, meu filho, sobre a terra, você, meu filho primeiro-último, o pequeno. Você, que em virtude de seu saber, terá conhecimento dos belamente adornados futuros. Assim que conhecer os adornados, carregará essa minha palavra a fim de fazê-la frutificar sobre a terra. Somente em virtude delas saberá a tarefa a cumprir sobre a terra.

Já desdobrada sua terra, que havia estabelecido em seu verdadeiro lugar, ele refletiu sobre sua tarefa futura: Quanto aos belamente adornados, quanto aos habitantes desiguais da terra, que saber tornaria visível ao conhecimento deles?

Tendo descido sobre a terra, foi o fogo futuro que soube no começo. Ele disse:

- É o fogo futuro que inicialmente diz respeito a minha tarefa futura, eu o sei. Por conseguinte, mensageiro, você, sapo, meu filho, me farei de morto, a fim de que aqueles que sabem da magia se voltem contra mim. Pois somente eles possuem o fogo sobre a terra: este deverá continuar em posse dos que existem imperfeitamente, a fim de que nossos filhos tenham consciência dele, os destinados a morar sobre a terra. Quanto a mim, me fingirei de morto, a fim de que o fogo dos que se voltam contra mim continue em posse de nossos filhos. Bem, sapo, meu filho, fique na espreita! Eu vou chacoalhar-me, e assim espalharei as brasas: engula-as, meu filho, engula-as!

Ele estica-se, deita-se. Nosso pai sabe então que seu filho está morto. Assim, diz ao futuro corvo:

- Bem, vá! Vejo que meu filho está bastante mal: vá vingar a Palavra de meu filho!

Veio o futuro corvo. Viu o que tinha sido um corpo e que era bem gordo. Junto de seus companheiros, acendeu uma fogueira para assá-lo. Trazendo lenha, acenderam-na sobre o cadáver. Foi então que Papa Miri sacudiu-se. E interrogou seu filho sapo, que disse:

- Não engoli!

Mais uma vez, ele deitou-se e fingiu-se de morto. Os que se voltavam contra ele reuniram-se novamente, trouxeram lenha e nela puseram fogo. Nosso pai sacudiu-se novamente. Interrogou seu filho sapo:

- Desta vez, engoli um pouco... Um pouquinho só!

- Bem, nesse caso, meu filho, vomite-o longe de você, para que meus filhos o peguem. Jogue-lhes!

Ele vomitou.

- Vá buscar um pedaço de madeira para que nela deixemos o fogo! 
Ele trouxe um galho de árvore aju_ joa, o loureiro.

- Deposite o fogo aí! E para depositá-lo, traga minha flecha com sua ponta.

Colocou as brasas no loureiro e deixou-as aí. À guisa de companheiro para o loureiro, trouxe o cipó rasteiro e nele também deixou as brasas. Neles dois deixou o fogo para os belamente adornados da terra, para que ele continue em mãos dos habitantes da terra.

Tendo feito isso, os futuros corvos voltaram para junto de nosso pai primeiro. Este sabia que haviam assado o que tinha sido um corpo:

- Vão embora! Sejam, doravante, aqueles a quem a coisa grande não inspirará nojo!

Os corvos choraram: não estavam destinados a viver na totalidade. Choraram" (Clastres, 1990: 103-105).

\section{O dono do fogo segundo os Yanomami}

A mitologia dos Yanomami tem características que a diferenciam de outras. Apesar de ter sido bastante bem documentada por grandes antropólogos, ainda não está publicada em português. No mito do fogo, registrado por Bruce Albert, o dono do fogo era o jacaré, que cuidadosamente o escondia dos outros, comendo taturanas assadas com sua mulher sapo, sem que ninguém soubesse. Ao resto do povo - animais que naquela época eram gente - eles só davam as taturanas cruas. O jacaré costumava esconder o fogo na boca. Os outros decidem fazer uma festa para fazê-lo rir e soltar as chamas. Todos fazem coisas engraçadas, mas o jacaré fica firme, no máximo dá um sorrisinho. Finalmente, um pássaro, possivelmente o cambaxirra-de-peito-branco, semelhante ao garrincha ou uirapuru, que é o último dançarino, consegue fazê-lo rir. Os outros tentam fugir com as brasas mas o sapo, que é a esposa do jacaré, consegue apagar o fogo jogando água. O povo do japuguaçu, então, transformado em pássaros, voam e salvam o fogo. O sapo não consegue impedir, e amaldiçoa as pessoas, dizendo que vão dormir perto do fogo, mas as crianças vão morrer, e que os mortos serão queimados no fogo, enquanto ela viverá no frio, nos rios. Jacaré fica tão assustado com o roubo que se joga no rio e vira o jacaré, passando a viver no frio, como sua mulher (Wilbert \& Sineoneau, 1990: 116-120).

\section{Incêndios}

Para os Suruí, houve um incêndio catastrófico quando os dois irmãos criadores, Palop e Palop Leregü (Nosso Pai e Nosso Pai de Roupa) resolveram roubar o machado do Pica-pau, Serepti. Furioso, este faz a floresta pegar fogo para que as labaredas os persigam e queimem. Palop Leregü refugiou-se no morro de cupim, e Palop caiu no rio. Quando o incêndio acabou, Palop saiu da água e encontrou o mato queimado; procurou o morro de cupim e só achou 
cinzas. Pôs-se a chamar o irmão. No início, não havia resposta. Palop soprou as cinzas, e aos poucos, uma vozinha se fez ouvir, e Leregü foi revivendo, até ficar em pé e reclamar com o irmão, que não tinha culpa: era o Pica-pau se vingando do roubo do machado (Mindlin et al., 1996: 77-78).

Neste mito, novo motivo foi acrescentado: o do sangue, e o da aranha, importante em outros povos, como os Tupari, para a criação das mulheres ou outros assuntos. É curioso pensar também que é possível resistir ao incêndio, usando como refúgio o morro de cupim.

Os Carajá, de Mato Grosso, contam de um incêndio mítico que destruiu a floresta e o povo. Ocorreu quando uma mãe não se conformou em se separar do filho de onze anos, levado para a Casa das Máscaras, onde ficam os meninos para a iniciação masculina. Chamou-o às escondidas, abraçou-o, lembrou-lhe os momentos de brincadeira e carinho, e o seduziu para revelar às mulheres os segredos das almas, só conhecidos dos homens. O menino, ainda entre criança e adolescente, cedeu à mãe. Quando os homens descobriram que o seu segredo fora revelado, puniram as mulheres, que agarraram, possuíram e sacrificaram. Um pajé tentou aplacar as almas e desapareceu no espaço, arrastando as máscaras sagradas. Foi então que as nuvens no céu se chocaram e provocaram lascas incandescentes, e um incêndio que reduziu as aldeias a cinzas (Peret, 1979: 59$62)$.

\section{O fogo e o sol}

Há ainda nestes povos Aruá, Jabuti, Macurap, vários mitos curiosos sobre a origem do sol, ausente em muitos outros relativamente próximos, como os Suruí, lembrando os múltiplos sóis dos Aztecas, que desaparecem sucessivamente.

No mito dos Aruá, o sol era como fogo, queimou uma criança e os homens o mataram. Vários sóis foram mortos pelos homens, até que o demiurgo, Paricot, resolveu elevar o céu para mais longe da terra.

No mito dos Jabuti de Rondônia, o sol nunca se punha, voltava imediatamente, nunca havia noite. Um dia, os "demônios" onças devoraram o sol, comiam também a humanidade. As mulheres grávida viravam onças, comendo os que haviam sido seus parentes. Os habitantes remanescentes na terra juntaram lenha e queimaram um pajé velho, para ficar no lugar do sol. O pajé foi se coçando no fogo, virando sol... não era mais gente, mas saiu muito namorador, excitando o ciúme dos homens, que o mataram. Outro pajé mais moderado foi escolhido, sentou-se na fogueira no seu banco de pajé, avisando os parentes para não chorarem, pois não iria morrer. Na fogueira, virou sol, o que existe hoje, e a ordem foi restaurada, não apareceram mais as onças monstruosas (Mindlin et al., 1999: 96-102). 


\section{A luz e o fogo imperfeito, consumidor de lenha}

Num mito muito especial dos Macurap de Rondônia, os motivos da transgressão erótica, fogo e escuridão se entrelaçam. Trata-se de uma moça casada que tinha um namorado secreto. Este costumava aproximar-se à noite, enfiava $\mathrm{o}$ braço pela parede de palha da maloca e acariciava a moça, que não cabia em si de felicidade, aproveitando durante o dia a satisfação noturna, ainda que dada de modo tão estranho. Com o tempo, porém, ela percebeu que seu clitóris crescia; cada vez maior, arrastava-se pelo chão, já se tornando impossível esconder a monstruosidade e o adultério.

Tornou-se patente que o namorado secreto não era um homem verdadeiro, aquele que a moça encontrava na floresta durante o dia, mas sim um fantasma Txopokod, um dos muitos que assolam os Macurap. A mãe e o marido da moça avisaram os habitantes da maloca, e quando o visitante apareceu para o namoro, os parentes dela cortaram o braço hábil e indiscreto e o jogaram na água fervente. O braço, porém, ficava ileso, não amolecia. E pior, já na hora do amanhecer, o escuro continuava. Enquanto o braço da aparição Txopokod permaneceu na maloca, a alternância de noite e dia ficou suspensa. Os Macurap tinham que alimentar o fogo com toda a lenha, finda a lenha com todos os objetos disponíveis, depois com o estoque de alimentos e milho, pois se ficassem no escuro, sem fogo, os Txopokod assustadores se vingariam e os matariam. Terminaram por decidir devolver o braço ao fantasma, que correu e se jogou no rio para se livrar da queimadura em sua carne (se é que espectros têm carne...). Dizem que até hoje esse rio é quente, por causa do braço fervente...

Quanto ao clitóris gigantes, foi cortado, transformando-se no poraquê. A ordem foi restaurada, e dia e noite voltaram a existir.

Este é um mito que à primeira vista parece não ter muita lógica. Sabemos, porém, que a mutilação do corpo aparece, em muitas histórias, associada à criação de astros, estrelas, à ordem cósmica. É a transgressão das regras da família e do amor tendo como resultado o desequilíbrio do universo, provocando o fim da luz, do sossego de dia e noite alternados. O fogo tem de ser mantido, o que é impossível sem o dia para a busca de lenha. Voltamos, de certa forma, ao fogo dos mortais a ser alimentado, o da Grécia. Quanto ao clitóris-poraquê, seria lícito pensar que contém a mesma energia elétrica que a do orgasmo, embora tão dissociado do resto do corpo....

Há um exemplo muito conhecido dos brasileiros, o da mutilação do corpo originando um astro. Trata-se da lua em Macunaima, de Mário de Andrade, que se inspirou num mito Kaxinauá. Neste mito, uma cabeça decepada persegue o irmão, que se esconde junto à mãe de ambos. Por sugestão desta, ao se ver indesejada, a cabeça rolante sobe para o céu por um cipó, e vira a lua. 
Este mito, sobre o qual não há espaço para falar neste artigo com a atenção e detalhe que lhe são devidos, é famoso e intrigante, tem desdobramentos e variações fantásticas nas Américas e já inspirou a Lévi-Strauss pelo menos um livro e meio (4).

\section{Dilúvios e fins do mundo}

O outro pólo dos incêndios e do descontrole do fogo é, nos mitos, o dilúvio ou inundações incontroláveis.

Em um dos mitos dos Gavião Ikolen de Rondônia, por exemplo, o Deus desprezado por algumas famílias, o demiurgo, vem com um bastão que afunda no chão em cada um dos cantos da maloca, nos quatro pontos cardeais. A água começa a jorrar dos furos que fez, inundando a terra. Só se salvam suas filhas e genros que o respeitaram, e a quem ensina que deveriam se refugiar na copa de uma palmeira. À medida que as águas vão subindo, a árvore vai crescendo, e assim sobreviveram ao fim trágico do povo alguns representantes da humanidade (5).

Os Gavião Ikolen são um povo de língua tupi-mondé. Os Guarani, que falam uma língua de outra família do tronco tupi, têm um mito semelhante sobre as águas exterminando a humanidade, em punição a um incesto. Há um casal que se salva - justamente o de transgressores - graças a uma palmeira pindo azul que surge no meio das águas. É um símbolo importante, que aparece, por exemplo, no final do romance O Guarani, de José de Alencar e em muitas obras de ficção.

Noutros povos, as inundações surgem de múltiplas formas. Nos Suruí, por exemplo, os dois criadores, Palop e Palop Leregü, foram a uma festa na casa de Tamoati, o Jacamim, como eles um dos primeiros seres do universo. Não se comportaram, e como costumam fazer os Suruí nas festas, ficaram bêbados e quebraram todas as panelas. Para puni-los, Tamoati prendeu-os numa cabaça e atirou-as ao rio. Ficaram boiando nas águas eternas, até Palop provocar um vento que faz a cabaça sair das águas, faz derreter a resina que servia de tampa, soltando-os. Noutros povos, como nos Aruá ou Macurap de Rondônia, os dois demiurgos destampam a fonte subterrânea da água e inundam a terra. Um deles morre afogado, ou é engolido pela traíra, e depois tem de ser ressuscitado pelo outro.

Poderíamos perseguir os mitos das águas assim como enveredamos um pouco pelos do fogo.

Como o fogo, as águas exterminadoras são o sinal do embate entre os mortais e os deuses, a separação, o fim da perfeição, que poderíamos seguir também nos mitos sobre a queda dos céus ou do paraíso, os mitos que relatam o aparecimento do trabalho em contraposição a uma abundância preexistente. Evocar o tema aquático é lembrar que este sentido da existência humana, sofredora, imperfeita e limitada, também pode ser atribuído ao fogo. 


\section{A friagem}

Para terminar, um último mito que faz referência a fenômenos climáticos poderia ser evocado, o da friagem, que, em Rondônia, repetindo-se durante dois ou três dias algumas vezes, anuncia o fim da estação das chuvas, com ventos fortes e gelados.

O narrador Konkuat Tupari conta a história de Sucai, o dono da friagem, que andava com o vento. Sucai fazia as águas secarem, deixava peixes, cobras e jacarés se debatendo no seco, assim fornecia alimento ao pescador que queria proteger, desde que esse mantivesse segredo sobre a pesca abundante. Mas com o tempo, o pescador sortudo contou aos outros porque trazia tanto peixe, e Sucai, que tudo ouve, mesmo de longe, mandou sua frigem e o matou, carregou seu espírito (Mindlin, 1993).

Transcrevemos uma segunda versão dessa história, narrada por Amonãi Manuel Tupari, vinda do além, incompreensível:

\section{"A friagem, ou a mulher que comeu a si mesma}

Antigamente sempre dava friagem, mais ou menos em maio, como dizemos hoje. Vem o vento antes da friagem, assoprando tudo, de uma vez, de uma tacada, um só, não tem outro depois. A friagem vem em seguida. Quando o vento nos assusta, já sabemos que Sucat, a friagem, está perto. Todo o ano acontece assim para nós.

Muitos pajés disseram que não era friagem, que era um bicho. É que primeiro, uns dois dias antes da friagem, vem só um sinal, um anúncio do que vai acontecer.

- Isso não é friagem, é um bicho, tarupá! Vamos tomar rapé, ver o que fazer!

Tomaram rapé para se defender, rezando, para o tarupá não fazer mal para ninguém.

Ficou essa mulher:

- Não vejo nada de perigoso, isso não é bicho! Não é friagem, nem tarupá, é vento qualquer. Eu não vou rezar, não vejo nada!

Era teimosa. Era como muito branco que teima, não quer ver a verdade, não acredita no que dizem os pajés.

Pelejaram para ela vir tomar rapé também, curar a friagem. Não quis, não tinha visto nada!

Um dia depois que recusou tomar rapé, começou. Começou a se comer. Comeu o dedo. Sozinha, ela mesma. Acabou a carne, foi de cada lado, cada pedaço do corpo. Comeu um braço, o outro; uma perna, a outra; a barriga, o peito, as costas, as partes, cada cantinho de si mesma. Parece que não doía. Comeu a perna, se enrolava de todo lado que queria, parece que não tinha osso! Ia se comendo. 
- Era para você vir atrás de reza, de rapé, veja o que aconteceu, você não acredita na palavra de pajé poderoso! Todos sabem que pajé não é brincadeira. Só você não quis obedecer os pajés, tomar rapé, você vai virar bicho, tarupá, do jeito que está se comendo!

Ficou mole, flexível, conseguia se dobrar como quisesse, para alcançar mais outro quinhãozinho da própria carne. Quando comeu o coração é que morreu" (Mindlin, 1999: 47-50).

É preciso explicar que Tarupás são fantasmas, assombrações maléficas, às vezes um pouco abobados, fáceis de enganar, mas perigosos. Os Tuparis também chamam de Tarupás os brancos, os estrangeiros, que trouxeram tantos males. Quanto ao rapé, é uma mistura de semente de angico e tabaco, às vezes com outros ingredientes, pó alucinógeno aspirado pelos pajés, que num ritual religioso o assopram nas narinas uns dos outros, abrindo caminho para os espíritos visitarem os mortais, curando doenças e trazendo fartura. Os que não são pajés, as mulheres e por vezes mesmo crianças, também podem aspirar.

A violência deste mito, chocante e inesperada, é mais um sinal do desafio humano aos deuses e do castigo pela arrogância. É possível encontrar semelhanças em mitos relativos ao ambiente, ao equilíbrio a ser mantido nas forças naturais. Há um mito grego-romano, por exemplo, em que um personagem, Erisychton, zomba dos deuses, e corta todas as árvores, desrespeitando até mesmo um carvalho sagrado que era santuário de Deméter, a Ceres dos romanos. A deusa o amaldiçoa, condenando-o a uma fome insaciável. Ele come tudo que lhe aparece pela frente, vende a própria filha para comprar alimentos. Mas nada é suficiente, e ele acaba por devorar a si próprio.

A crueldade do mito indígena aparece também em outras mitologias - sanção violenta contra a desobediência à ordem divina.

\section{Conclusão}

O fio de Ariadne, seguido nesse artigo para entrar e emergir do labirinto de mitos, pode não ter conduzido a uma luz e a um fogo redentores da saída, mas deve ter mostrado a complexidade de lidar com esse universo. Poderíamos continuar, buscando e encontrando múltiplas versões do roubo do fogo e dos incêndios em povos indígenas da América do Norte ou da África - um jogo sem fim. Ou poderíamos perseguir os muitos temas correlatos do cosmos, do aparecimento das estrelas, das Plêiades, do sol e da lua. Cada vez estaremos mergulhando em outros significados, outros ângulos para compreender a linguagem imaginária e simbólica. Italo Calvino, na introdução às suas Fábulas, diz acreditar que aquelas histórias são verdadeiras, pois são uma explicação geral da vida. O mesmo poder-se-ia dizer dos mitos indígenas - contam sobre a experiência dos seres humanos, sobre fenômenos naturais e o que se passou com o universo e com a terra - só que a verdade que contêm, possivelmente não é literal, mas 
depende do eco que acorda nos ouvintes e nos leitores, de acordo com seu repertório cultural e as ligações que conseguem estabelecer entre os mitos e com a sua substância, revelando um sentido oculto e profundo a ser reinventado.

\section{Notas}

1 Nova Enciclopédia Ilustrada da Folha de São Paulo

2 Ver, por exemplo, sua excelente introdução ao livro de Ives Bonnefoy, American, African and old European mythologies, Chicago, Chicago University Press, 1993, p. 3-5

3 Algumas obras importantes são: León Cadogan, Ayvu Rapyta, textos miticos de los Mbyá-Guaraní del Guairá, edição preparada por Bartomeu Melià, Assunção, Ceaduc/ Cepag, 1992; Pierre Clastres, A fala sagrada, Campinas, Papirus, 1990; Curt Nimuendaju Unkel, As lendas da criação e destruição do mundo como fundamentos da religião dos Apapocúva-Guarani, São Paulo, Hucitec/Edusp, 1987; Egon Schaden, Aspectos fundamentais da cultura guarani, São Paulo, EPU/Edusp, 1974.

4 Claude Lévi-Strauss, L'origine des manières de table, Paris, Plon, 1968 e A oleira ciumenta, São Paulo, Brasiliense, 1986. Ver também comentários de Betty Mindlin sobre este mito, A cabeça voraz. Estudos Avançados, v. 10, n. 27, p. 271-284, maio/ ago. 1996, ilustrações de Adão Pinheiro, e Uma bruxa nordestina: um tesouro Tremembé, Itinerários, Araraquara, n. 13, 1998

5 Betty Mindlin, Catarino Sebirop Gavião, Digüt Tsorabá Gavião e outros narradores indígenas, Couro dos espíritos, São Paulo, SENAC/Terceiro Nome, no prelo.

Referências bibliográficas

AGOSTINHO, Pedro. Mitos e outras narrativas Kamaiurá. Bahia, Universidade Federal da Bahia, 1974.

ALBISETTI, César \& VENTURELLI, Ângelo J. Enciclopédia Bororo, v. 2. Campo Grande, Museu Regional Dom Bosco, 1969.

BONNEFOY, Ives. American, African and old European mythologies. Chicago, Chicago University Press, 1993.

CADOGAN, Leon. Ayvu Rapyta, textos miticos de los Mbyá-Guarani del Guairá, edição preparada por Bartomeu Melià. Assunção, Ceaduc-Cepag, 1992.

CAMPBELL, Joseph. O poder do mito. São Paulo, Palas Athena, 1990.

CLASTRES, Pierre. A fala sagrada, Campinas, Papirus, 1990.

LÉVI-STRAUSS, Claude. Antropologia estrutural. Rio de Janeiro, Tempo Brasileiro, 1967. L’origine des manières de table. Paris, Plon, 1968. 
LÉVI-STRAUSS, Claude. A oleira ciumenta. São Paulo, Brasiliense, 1986. O cru e o cozido, Mitológicas I. São Paulo, Brasiliense, 1991.

MINDLIN, Betty. Tuparis e tarupás. São Paulo, Brasiliense/Edusp/IAMÁ, 1993. . A cabeça voraz. Estudos Avançados, v. 10, n. 27, p. 271-284, maio/ ago. 1996, ilustrações de Adão Pinheiro.

Uma bruxa nordestina: um tesouro Tremembé. Itinerários, n. 13, Araraquara, 1998.

rio, dez. 1999.

A mulher que comeu a si mesma. Libertárias 5, São Paulo, Imaginá-

MINDLIN, Betty \& RAMOS, José Ademir (orgs.). Sehay Kaat Haria, o caçador de histórias, Narrativas dos Sateré-Mawé do Marau. São Paulo, Instituto de Estudos Avançados/IAMÁ, 1996.

MINDLIN, Betty e narradores indígenas. Vozes da origem. São Paulo, Ática/IAMÁ, 1996.

O machado de Serepti, in Vozes da origem. São Paulo, Ática/IAMÁ,

1996.

Terra grávida. Rio de Janeiro, Rosa dos Tempos/Record, 1999.

MINDLIN, Betty; GAVIÃO, Catarino Sebirop; GAVIÃO, Digüt Tsorabá e outros narradores indígenas. Couro dos espiritos. São Paulo, SENAC/Terceiro Nome, no prelo.

PAZ, Octávio. Claude Lévi-Strauss o el nuevo festin de Esopo. México, Joaquin Mortiz, 1967.

PEREIRA, Nunes. Moronguêtá, um Decameron Indigena, 2 v. Rio de Janeiro, Civilização Brasileira, 1967.

PERET, João Américo. Mitos e lendas Karajá, Inã Son Wera. Rio de Janeiro, edição do autor, 1979.

PROPP, Vladimir. Morphologie du conte. Paris, Seuil, 1970.

PROPP, Vladimir. Les racines historiques du conte merveilleux. Paris, Gallimard, 1983.

SCHADEN, Egon. Aspectos fundamentais da cultura guarani, São Paulo, EPU/Edusp, 1974.

UNKEL, Curt Nimuendaju. As lendas da criação e destruição do mundo como fundamentos da religião dos Apapocúva-Guarani. São Paulo, Hucitec/Edusp, 1987.

VERNANT, Jean Pierre. Mito e pensamento entre os gregos. São Paulo, Difel, 1973. Mito e religião na Grécia antiga. Campinas, Papirus, 1992. As origens do pensamento grego. Rio de Janeiro, Bertrand Brasil 1994.

2000. O universo, os deuses, os homens. São Paulo, Companhia das Letras, 
VERNANT, Jean Pierre \& VIDAL-NAQUET, Pierre. Mito e tragédia na Grécia antiga. São Paulo, Brasiliense, 1988.

VILLAS BOAS, Orlando \& VILLAS BOAS, Cláudio. Xingu, os indios, seus mitos. Rio de Janeiro, Zahar, 1972.

Von FRANZ, Marie Louise. Creation myths. Patterns of creativity mirrored in creation myths. Zurich, Spring Publications, 1972.

WILBERT, Johannes. Folk literature of the Gê Indians, v. II. Los Angeles, UCLA, 1984.

WILBERT, Joahnnes \& SIMONEAU, Karin. Folk literature of the Yanomami Indians. Los Angeles, UCLA, 1990.

Betty Mindlin é doutora em antropologia pela Pontifícia Universidade Católica de São Paulo e mestre em economia pela universidade de Cornell, EUA. É pesquisadora do IAMÁ - Instituto de Antropologia e Meio Ambiente e ex-professora visitante do Instituto de Estudos Avançados. É autora, em conjunto com narradores indígenas, de Couro dos espíritos, Senac/Terceiro Nome (no prelo) e outros quatro livros de mitos indígenas, além de outras obras e numerosos artigos publicados no Brasil e no exterior. 